Mycologia, 99(6), 2007, pp. 877-883.

(C) 2007 by The Mycological Society of America, Lawrence, KS 66044-8897

\title{
Genetic variability of Phytophthora sojae isolates from Argentina
}

\author{
Marcela Gally ${ }^{1}$ \\ Fitopatología, Facultad de Agronomia, Universidad de \\ Buenos Aires, Avenida San Martín 4453, 1417 Buenos \\ Aires, Argentina \\ Araceli Marcela Ramos \\ Diana Dokmetzian \\ Silvia Edith Lopez \\ Departamento de Biodiversidad y Biología \\ Experimental, Facultad de Ciencias Exactas y \\ Naturales, PROPLAME-PRHIDEB-CONICET, \\ Universidad de Buenos Aires, Ciudad Universitaria, \\ 1428 Buenos Aires, Argentina
}

\begin{abstract}
Phytophthora sojae causes root and stem rot, one of the most important diseases of soybean worldwide. Genetic diversity of 32 Phytophthora sojae isolates of different geographic origin from Argentina was evaluated with RAPD markers. The isolates were collected from diseased soybean plants and soil samples from Santa Fe, Buenos Aires, Córdoba and Entre Ríos provinces, in the Pampeana Region. DNA was amplified with 20 decanucleotides primers. Seven primers amplified 49 fragments, of which 35 were polymorphic, indicating high variability. RAPD analysis detected intraspecific variability even among isolates of the same geographic origin.
\end{abstract}

Key words: Argentina, Phytophthora root rot, RAPD, soybean

\section{INTRODUCTION}

Argentina is the primary exporting country of soybean meal and oil, and third exporter of grain, after USA and Brazil. Soybean production rose to 38300000 metric tons from 144000000 hectares in 2004/2005 growing season. Yield losses for the 1997/ 1998 growing season were estimated at 8\% (Wrather et al 2001) and more recently at $8-10 \%$ (Vallone 2002). During the past decade the situation has worsened due to the widespread use of no-till practices, soybean monocropping and genetic uniformity of cultivars. Late season diseases and several root rot diseases presently are among the most damaging pathologies. Phytophthora root rot (PRR) of soybean (Glycine $\max$ L. Merr.) caused by Phytophthora sojae Kaufmann and Gerdemann, first was noted in Argentina in southern Santa Fe and northern Buenos Aires provinces in Pampeana Region (PR) in the

Accepted for publication 11 August 2007.

${ }^{1}$ Corresponding author. E-mail: mgally@agro.uba.ar 1970s (Martínez and Ivancovich 1979). In 1989 the pathogen was isolated and identified by Barreto et al (1991). From 1991 to 1992 isolated outbreaks were recorded (Barreto et al 1995). Since then prevalence of the disease has continued to increase and it has become epidemic (Barreto et al 1998, Vallone et al 1999). Incidence registers for PRR rose to $60 \%$ in Pergamino, Buenos Aires, and 70\% in Marcos Juárez, Córdoba (Vallone et al 1999).

$P$. sojae is a homothallic Oomycota with more than 50 races described worldwide. In Argentina race 1 was identified in 1989 (Barreto et al 1991) and prevailed for several years, but increasing variability in pathogenicity has been reported (Barreto et al 1997, 1998; Gally et al 1999). The knowledge of pathogenic composition of populations is essential for addressing local breeding programs but demands significant amounts of time and space.

Molecular technologies have been applied recently to study genetic variation in plant pathogen populations. Direct analysis of DNA polymorphisms is a reliable approach to detect genetic variation, and random amplified polymorphic DNA (RAPD) (Williams et al 1990) is a powerful tool for such detection. This method uses primers of arbitrary sequence, which allows an extensive random sampling of the genome. For this reason RAPD has been used to detect genetic variation at the species level (McDermont et al 1994, Gosselin et al 1996, Frazzon et al 2002, Doherty et al 2003, Silva et al 2003, Gouveia et al 2005, Zhou et al 2005).

RAPD has been used to estimate genetic diversity of other Phytophthora species (Chang et al 1996, Peters et al 2005). Whisson et al (1994) used RAPD and other molecular techniques to establish the genetic relation among species of the $P$. megasperma complex. RAPD technology also has been used to confirm sexual recombination of $P$. sojae in vitro and to study the segregation of avirulence genes (Whisson et al 1994). Meng et al (1999) used RAPD markers to study populations of $P$. sojae from Indiana, Iowa and Minnesota and found no correlation of populations with geographic origin. Wang et al (2003) analyzed genetic diversity of isolates from China and the United States through RAPD and distinguished 12 genetic groups. RAPD markers also were used to detect interspecific hybrids between $P$. sojae and $P$. vignae (Drenth et al 2003).

The aim of this study was to estimate genetic variability of isolates of $P$. sojae from Argentinean provinces and to estimate phenetic relationships among 32 Argentinean isolates. 
TABle I. Origin of Argentine isolates of P. sojae in this study

\begin{tabular}{|c|c|c|c|}
\hline $\begin{array}{l}\text { Number } \\
\text { of isolate }\end{array}$ & Locality & Province & $\begin{array}{l}\text { Isolated } \\
\text { from plant } \\
\text { (P) or } \\
\text { soil (S) }\end{array}$ \\
\hline $15,21,34,36,126$ & Ocampo & Buenos Aires & $\mathrm{P}$ \\
\hline 62,64 & Ocampo & Buenos Aires & $\mathrm{S}$ \\
\hline $89,123,153,282$ & Pergamino & Buenos Aires & $\mathrm{P}$ \\
\hline 174,175 & Pergamino & Buenos Aires & $\mathrm{S}$ \\
\hline 165,178 & $\begin{array}{l}\text { Rafael } \\
\text { Obligado }\end{array}$ & Buenos Aires & $\mathrm{S}$ \\
\hline 501,502 & Hughes & Santa Fe & $\mathrm{P}$ \\
\hline $500,503,504,505$ & Hughes & Santa Fe & $\mathrm{S}$ \\
\hline 149,180 & Godeken & Santa Fe & $\mathrm{P}$ \\
\hline 177 & Godeken & Santa Fe & $\mathrm{S}$ \\
\hline 49 & Bigand & Santa Fe & $\mathrm{P}$ \\
\hline 370 & Los Molinos & Santa Fe & $\mathrm{S}$ \\
\hline $52,55,75$ & Marcos Juárez & Córdoba & $\mathrm{P}$ \\
\hline 168,211 & Marcos Juárez & Córdoba & $\mathrm{S}$ \\
\hline 600 & Gualeguaychú & Entre Ríos & $\mathrm{P}$ \\
\hline
\end{tabular}

\section{MATERIALS AND METHODS}

Thirty-two $P$. sojae isolates from diseased plants and infested soils from Buenos Aires, Córdoba, Santa Fe and Entre Ríos provinces, supplied by Dora Barreto from the Instituto Nacional de Investigaciones Agropecuarias (Argentina), were used in the study (TABLE I). Two isolates from Canada, one from Essex (isolate CA1A4) and one from Ottawa (CA9826), supplied by Terry Anderson from the Agriculture and Agrifood Research Centre, were included as controls.

Growth in liquid media.-Erlenmeyer flasks containing $25 \mathrm{~mL}$ of liquid V8 medium (40 mL V8 juice, $1 \mathrm{~g}$ sucrose, $0.6 \mathrm{~g} \mathrm{CaCO}_{3}, 0.2 \mathrm{~g}$ yeast extract and $0.01 \mathrm{~g}$ cholesterol/L of bidistilled water) were inoculated by transferring a $5 \mathrm{~mm}$ disk cut from the margin of a $5 \mathrm{~d}$ old colony growing on VA medium (V8 medium with $2 \%$ agar). Cultures were grown at $24 \mathrm{C}$ in a New Brunswick G-27 incubator chamber at $23 \mathrm{C}$. The mycelium was harvested on the fifth d (Gally et al 2003), vacuum filtered in a Buchner funnel through filter paper, rinsed three times with bidistilled water, fractionated and kept at $-70 \mathrm{C}$ until used.

DNA extraction.-Genomic DNA was extracted from mycelia (Dellaporta et al 1983). DNA concentration was estimated by comparing electrophoretic patterns on $0.8 \%$ agarose (in $1 \times$ TAE buffer) gels with standard DNA marker sets (phage $\lambda$ double digested with EcoRI and HindIII).

Polymerase chain reaction.-PCR was carried out in $50 \mu \mathrm{L}$ final volume with 40-60 ng genomic DNA, $5 \mu \mathrm{L}$ L dNTP $\operatorname{mix}(100 \mathrm{mM}), 6 \mu \mathrm{L} \mathrm{L} \mathrm{MgCl}_{2}(25 \mathrm{mM}), 10 \mu \mathrm{L} \mathrm{L}$ primer $(3 \mathrm{ng} / \mathrm{mL}), 5 \mu \mathrm{L} \mathrm{L} 10 \times$ Taq DNA polymerase buffer (10 mM tris- $\mathrm{HCl}, \mathrm{pH} 9.0$ at $25 \mathrm{C}, 50 \mathrm{mM} \mathrm{KCl}, 0.1 \%$ Triton $\mathrm{X}-100)$ and $0.5 \mu \mathrm{L} \mathrm{L}$ Taq DNA polymerase (Promega) $(0.5$ units $/ \mu \mathrm{L})$. The mixture was amplified in a thermal cycler (Techne Gene E). The thermal cycler was pro- grammed for one cycle of $94 \mathrm{C}$ for $6 \mathrm{~min}$; 45 cycles of $94 \mathrm{C}$ for $1 \mathrm{~min}, 36 \mathrm{C}$ for $1 \mathrm{~min}$ and $72 \mathrm{C}$ for $2 \mathrm{~min}$, followed by a final extension step of $72 \mathrm{C}$ for $6 \mathrm{~min}$.

Two PCR amplifications per isolate were carried out to ensure reproducibility of banding patterns. Measures were taken to prevent contamination of PCR experiments with previously amplified fragments; in particular pre- and postamplification procedures were separated and fresh aliquots of reagents were used for each experiment wherever possible. To test the reliability of PCR products several controls were used routinely, one without primer, a second without Taq DNA polymerase and the third with no genomic DNA.

Primers. - Twenty arbitrary primers (Promega, series A and B) were screened for suitability in a small number of individuals. Only those primers that produced clear and reproducible RAPD bands for all fungal isolates were chosen.

DNA fragment analysis. - Amplification products were resolved on $1.4 \%$ agarose gels stained with $\mathrm{EtBr}(0.5 \mu \mathrm{g} / \mathrm{mL})$. Fragments were observed and photographed on a UV transilluminator $(312 \mathrm{~nm})$.

Statistical methods.-RAPD bands were scored as present (1) or absent (0) across all genotypes to create a binary matrix, which was analyzed with the program NTSYS-PC version 1.8 (Rohlf 1993). The unweighted pair-group arithmetic mean method (UPGMA) cluster analysis was performed based on the simple matching (SM), Jaccard (J), and Dice (D) association coefficients (Sneath and Sokal 1973). Phenograms showing similarity relations were generated by the same program, with the tree display option (TREE). Correlation cophenetic coefficients ( $r$ ) were calculated for each association coefficient (Sokal and Rohlf 1962). A cophenetic correlation of $r>0.8$ was considered a good fit. A three-dimensional graphic was obtained with the principal coordinates ordination method (Gower 1966).

The ability of the primers to differentiate among isolates was assessed by calculating their resolving power (Rp) (Prevost and Wilkinson 1999). Genetic variability among isolates from Buenos Aires, Córdoba and Santa Fe provinces was quantified by the percentage of polymorphic loci $(\mathrm{P}=$ number of polymorphic loci/number of loci analyzed) and the mean heterozygosity (He) (Nei 1978). The percentage of polymorphic loci and the mean heterozygosity $(\mathrm{He})$ were estimated from allelic frequencies by Biosys 1.7 (Swofford and Selander 1981).

\section{RESULTS}

Characterization of RAPD markers.-Of the 20 primers screened seven produced clear and reproducible bands by RAPD amplification for all isolates. The seven primers A01 (5'CCC AAG GTC C3'), A02 (5'GGT GCG GGA A3'), A03 (5'AAG ACC CCT C3'), A5 (5'CAC CAG GTG A3'), A6 (5'GAG TCT CAG G3'), A10 (5'ACG GCG TAT G3'), and B06 (5'GTG ACA TGC C3') were used for the analysis. They 
TABLE II. Data pertinent to six primers. $\mathrm{B}=$ number of total bands, $\mathrm{PB}=$ number of polymorphic bands, $\mathrm{Rp}=$ resolving power and $\mathrm{P} \%=$ percentage of polymorphic loci

\begin{tabular}{lrcrr}
\hline Primer & B & PB & \multicolumn{1}{c}{ Rp } & P\% \\
\hline A01 & 5 & 3 & 9,1 & 60 \\
A02 & 6 & 5 & 7,11 & 83 \\
A03 & 10 & 9 & 13,6 & 90 \\
A06 & 8 & 6 & 13,56 & 75 \\
A10 & 6 & 4 & 7,72 & 67 \\
B06 & 9 & 9 & 8,22 & 100 \\
\hline
\end{tabular}

allowed the scoring of 49 bands that appeared consistently in all experiments among the amplified fragments of the 34 isolates. The $\mathrm{Rp}$ of the primers varied from 7.1 for A02 primer to 13.6 for A03 primer (TABLE II). Primers A03 and B06 were more effective in detection of polymorphisms. All bands produced with primer B06 were polymorphic across all isolates. Primer A05 was monomorphic and was not included in the table. Thirty-five $(71 \%)$ of the total bands were polymorphic, suggesting high genetic variability among the isolates.

Isolates from Buenos Aires Province presented the highest genetic variability and isolates from Córdoba the lowest. Results of isolates from Santa Fe were intermediate (TABLE III).

Cluster analysis. - Three phenograms were obtained based on Jaccard, simple matching and Dice coefficients. High levels of correlation cophenetic coefficients were achieved by the three association coefficients used, indicating low distortion, 0.82 by Jaccard and 0.84 by simple matching and Dice. Dice was chosen for the analysis. The phenogram showed that the relatedness of the 34 isolates of $P$. sojae was $0.76-$ 1.0 (FIG. 1). Grouping analysis revealed that 30 isolates clustered in one group (FIG. 1, group G1) with an origin of ramification in 0.87 . A second group (FIG. 1, group G2) included only three isolates, 126, 503 and 178. Isolate 15 from Manuel Ocampo, Buenos Aires, was genetically unique as it was sister of the other 33 isolates, according to analysis (FIG. 1). It presented the lowest values of Dice coefficient, even with respect to isolates of the same province and the same locality (data not shown). The main group (FIG. 1, group G1) comprised two subgroups (FIG. 1, groups SG1 and SG2). Group SG1 with 21 isolates included two conjuncts (C1 and C2), a nucleus of two isolates (89 and 52) and two isolates separated from the rest, one of which was CA9826, from Ottawa, Canada. Group SG2 comprised two conjuncts (FIG. 1, groups C3 and C4). Control isolates from Canada were included in SG1 with 19 Argentinean isolates, which indicated a high degree of similarity among them.
TABLE III. Genetic variability of isolates of $P$. sojae from each province. $\mathrm{P} \%=$ percentage of polymorphic loci, $\mathrm{He}=$ mean heterozygocity (standard errors in parentheses)

\begin{tabular}{lccc}
\hline \hline \multicolumn{1}{c}{ Province } & $\begin{array}{c}\text { Mean sample } \\
\text { size per locus }\end{array}$ & $* \mathrm{P}$ & $* * \mathrm{He}$ \\
\hline Buenos Aires & 15.0 & 77.8 & $0.315(0.03)$ \\
Santa Fe & 11.0 & 58.3 & $0.237(0.04)$ \\
Córdoba & 5.0 & 33.3 & $0.162(0.04)$ \\
\hline
\end{tabular}

* P: percentage of polymorphic loci.

**He: mean heterozygocity.

Only two pairs of isolates presented $100 \%$ of similarity (association coefficient 1.0), and they belonged to different conjuncts of group SG1; isolates174 and 153, both from Pergamino, Buenos Aires, were in group C2; isolates 211 and 505 from Córdoba and Santa Fe respectively were in group C1.

The ordination of isolates through the principal coordinates method let us distinguish five groups (FIG. 2, groups GI to GV) in three-dimensional dispersion and showed nearly the same relations between isolates as the phenogram (FIG. 1). Group GI included isolates of C1 of the phenogram, group GII comprised the remainder of isolates of SG1, group GIII comprised all isolates of C3 (in SGII of the phenogram), group GIV comprised the isolates of C4 and the isolate 15 and Group GV included isolates 178,126 and 503, which were clustered in a separated group in the phenogram (G2).

\section{DISCUSSION}

The main factors that contribute to genetic changes within fungi populations are mutation, mating system, gene flow, migration, population size and selection. However in agricultural ecosystems pathogen populations evolve adapting to constant changes in environment conditions, such as the use of resistant varieties, applications of fungicides and fertilizers, irrigation and crop rotation. These changes impose a strong directional selection, which may be the main force acting in these systems (McDonald 1997).

The evolution of populations of P. sojae in USA and Canada has responded mainly to the resistance genes included in the commercial genotypes of soybean cultivated (Hobe 1981, Buzzell and Anderson 1982, Schmitthenner 1994).

Although populations of $P$. sojae in soil usually present high variability, the origin of that variability has not been elucidated fully (Forster et al 1994). A high degree of homozigosis of populations of $P$. sojae could be presumed due to its homothallic character (Tyler et al 1995). However a high level of heterozygosity was 


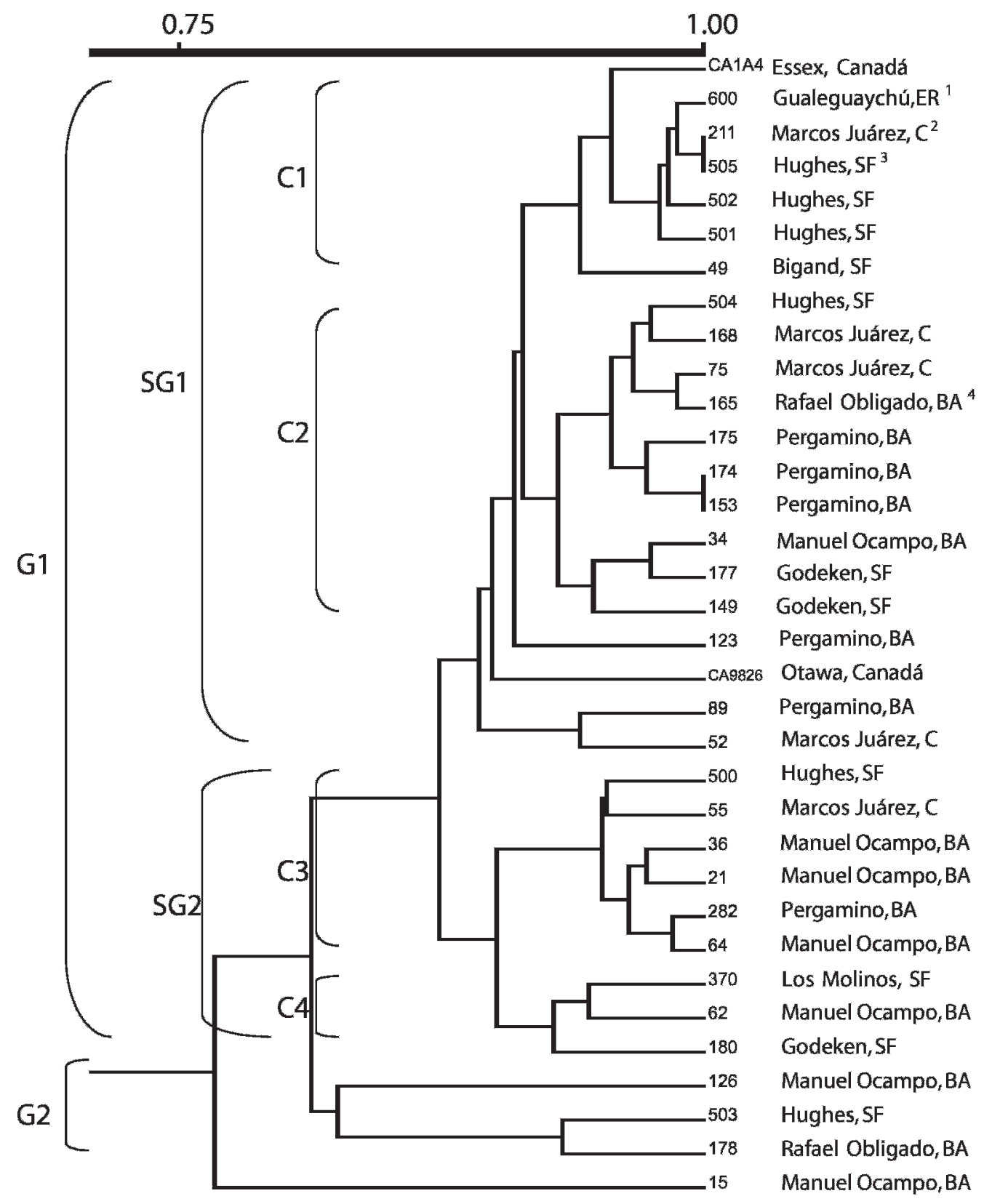

FIG. 1. Phenogram of the relationships between $P$. sojae isolates based on RAPD analysis (Dice coefficient). ${ }^{1}$ Entre Ríos, ${ }^{2}$ Córdoba, ${ }^{3}$ Santa Fe, ${ }^{4}$ Buenos Aires.

reported for virulence genes (Bhat and Schmitthenner 1993). Sexual recombination between pathotypes has been demonstrated in vitro and is presumed to play an important roll in the generation and maintainance of genetic diversity in the field (Bhat and Schmitthenner 1993, Tyler et al 1995, Whisson et al 1994). Parasexual recombination, also demonstrated in vitro (Long and Keen 1977, Layton and Khun 1989), may be a less important factor because of its low frequency in field conditions and the adaptative advantage of sexual populations, considering the longer viability of oospores compared to zoospores (Goodwin 1997). In this study RAPD markers were useful for detecting high genetic variability among Argentinean isolates of $P$. sojae. Genetic structure of a population reflects its evolutionary history and its potential to evolve (McDonald 1997). Considerable diversity within Buenos Aires and Santa Fe isolates suggests rapid evolution. The higher variability found in Buenos Aires probably is related to a longer evolution compared to the other sites. P. sojae first was isolated in 1989 from diseased plants from Pergamino, north of Buenos Aires (Barreto et al 1991). From 1989 to 1992 the disease was detected only in the same area, and as growers 


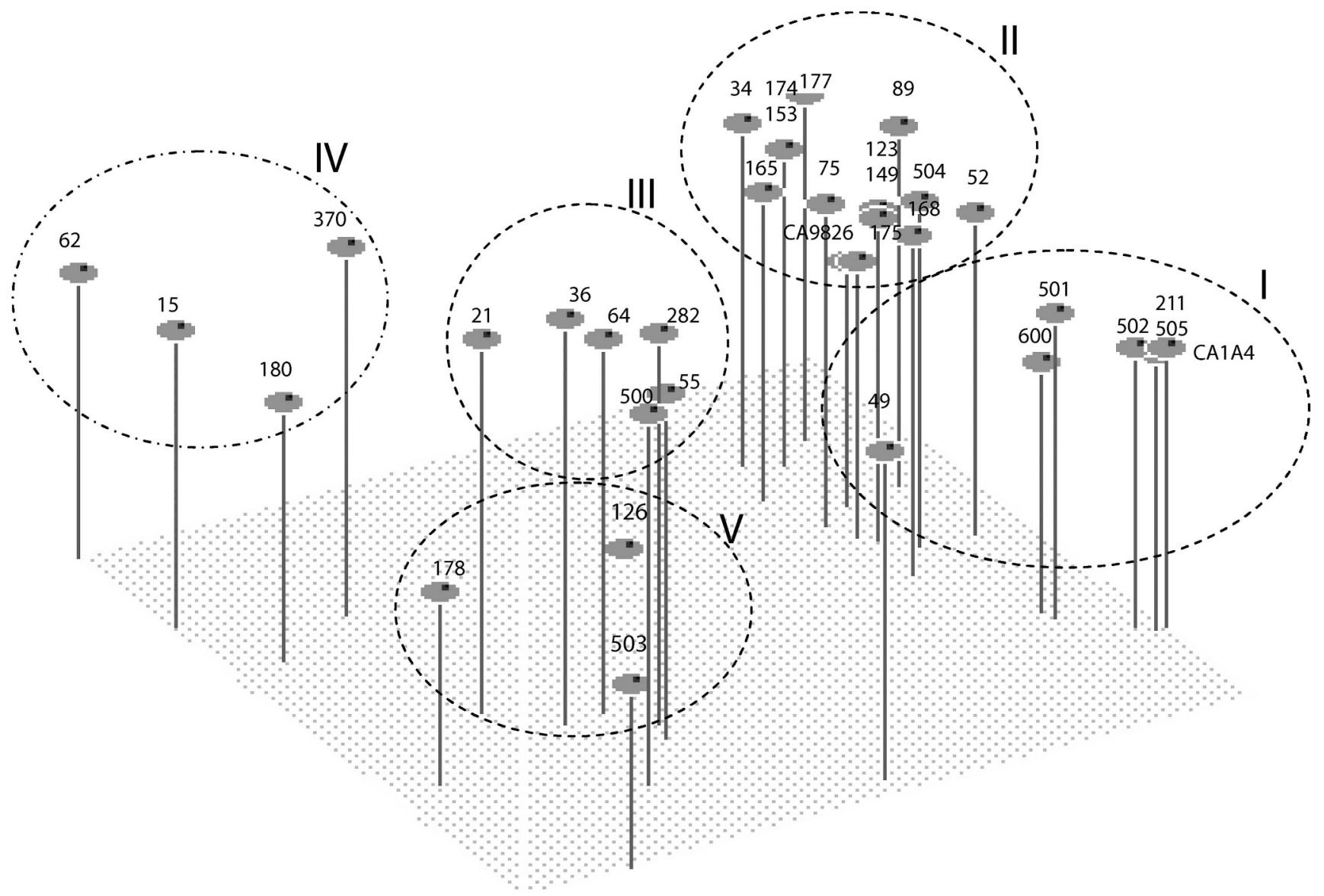

FIG. 2. Grouping of isolates through the principal coordinates method.

adopted conservation tillage systems and continued monocropping the disease began to spread and was detected in other provinces (Ploper 2004). The lower variability obtained from Córdoba isolates probably is related to the fact that they were collected from the same locality.

The range of amplification products obtained with the seven primers in this study clearly demonstrated high intraspecific variation among $P$. sojae isolates even from the same location. Molecular variation yielded up to $71 \%$ of polymorphic bands, which represents high degree of polymorphism. The isolates from Canada, used as controls, were clustered in the same subgroup with 19 Argentinean isolates, which indicated a high degree of similarity among them. This arrangement confirmed that with the primers used in this study we did not find any relation between the grouping of isolates and their geographic origin. These results can be compared with those of Wang et al (2003) who used RAPD markers to analyze 75 isolates from China and 11 from USA. They found 12 genetic groups but most of the isolates (44 Chinese and 10 American) were included in one group and no relationship between clustering and geographic ori- gin was found. That study indicated a higher level of polymorphism than in the Argentinean isolates. Meng et al (1999) also found genetic diversity among isolates of $P$. sojae, with four distinct groups obtained by RAPD, with no relationships detected with geographic origin of isolates, the same finding of Peters et al (2005) with $P$. erythroseptica.

Our study indicates that $P$. sojae is a highly variable pathogen in Argentina because great variability was found among isolates from the same locality, and thus RAPD markers are useful to detect intraspecific genetic variation. Its rapid evolution and high genetic diversity indicates increasing fitness of the population, which might improve the pathogen's abilities to overcome single gene resistance, widely used to manage Phytophthora root rot of soybean. This paper constitutes the first report of genetic variability in $P$. sojae populations from Argentina.

\section{ACKNOWLEDGMENTS}

We thank Dr Laura Ferreyra for her critical revew of the manuscript and Dr Terry Anderson and Dora Barreto for their kindly collaboration with some strains. 


\section{LITERATURE CITED}

Barreto D, Anderson T, Gally M, Grijalba P. 1998. Evaluation of Phytophthora sojae from Argentine soybean fields. In: Proceedings 7th International Congress of Plant Pathology, Edinburgh, Scotland. 1:6.

—, Gally M, Grijalba P. 1997. Razas de Phytophthora sojae en la Región Pampeana (Argentina) en un intervalo de 8 años. In: Actas IX Congreso Latinoamericano de Fitopatología. Montevideo, Uruguay. 219 p.

—_- Stegman B, Fortugno C. 1991. Phytophthora megasperma f.sp. glycinea: detección y virulencia del patógeno. In: Actas Primera Reunión Nacional de Oleaginosas, p 304-311.

$\longrightarrow,-1$. 1995. Races of Phytophthora sojae in Argentina and reaction of soybean cultivars. Plant Dis 79:599-600.

Bhat RG, Schmitthenner AF. 1993. Genetic crosses between physiological races of Phytophthora sojae. Exp Mycol 17: 122-129.

Buzzell RI, Anderson TR. 1982. Plant loss response of soybean cultivars to Phytophthora megasperma f. sp. glycinea under field conditions. Plant Dis 66:11461148.

Chang TT, Yang WW, Wang WY. 1996. Use of random amplified polymorphic DNA markers for the detection of genetic variation in Phytophthora cinnamoni in Taiwan. Bot Bull Acad Sinica 37:165-171.

Crowhurst RN, Hawthorne BT, Rikkerink EH, Templeton MD. 1991. Differentiation of Fusarium solani f. sp. cucurbitae races 1 and 2 by random amplification of polymorphic DNA. Curr Genet 20:391-396.

Dellaporta SL, Wood J, Hicks JB. 1983. A plant DNA minipreparation: version II. Plant Molec Biol Rep 1:1921.

Doherty KR, Zweife LEW, Elde NC, McKone MJ, Zweifel SG. 2003. Random amplified polymorphic DNA markers reveal genetic variation in the simbiotic fungus of leafcutting ants. Mycologia 95:19-23.

Forster H, Tyler BM, Coffey MD. 1994. Phytophthora sojae races have arisen by clonal evolution and by rare outcrosses. Molec Plant-Microbe Interact 7:780-791.

Frazzon APG, Matsumara ATS, van der Sand ST. 2002. Morphological characterization and genetic analysis of Drechslera teres isolates. Genet Molec Biol 25:235-241.

Gally M, Grijalba P, Barreto D. 1999. Investigación sobre Phytophthora sojae (campaña 1997/98): relevamiento, aislamiento y prueba de material genético. In: Actas X Jornadas Fitosanitarias Argentinas, San Salvador de Jujuy, Apr 1999. 48 p.

- Lopez SE, Dokmetzian DA, Ramos AM, Barreto DE. 2003. Cinética de crecimiento in vitro de cepas argentinas de Phytophthora sojae. Rev Investig Agropecuarias, INTA 32(1):39-48.

Goodwin SB. 1997. The population genetics of Phytophthora. Phytopathology 87:462-473.

Gosselin L, Jobidon R, Bernier L. 1996. Assessment of genetic variation with Chondrostereum purpureum from Québec by random amplified polymorphic DNA analysis. Mycol Res 100:151-158.
Gouveia MC, Ribeiro A, Várzea VMP, Rodríguez CJ. 2005. Genetic diversity in Hemileia vastatrix based on RAPD markers. Mycologia 97:396-404.

Hobe MA. 1981. Pathogenic variability of Phytopthora megasperma f. sp. glycinea isolated from northwest Ohio soybean soils (Master's thesis). Columbus: Ohio State University.

Layton AC, Kuhn DN. 1989. In planta formation of heterokaryons of Phytophthora megasperma f. sp. glycinea. Phytopathology 78(7):961-966.

Long M, Keen NT. 1977. Evidence for heterokaryosis in Phytophthora megasperma var. sojae. Phytopathology 67: 670-674.

Martinez C, Ivancovich A. 1979. Presencia de Phytophthora megasperma var. sojae en la Pampa Húmeda. In: Actas Reunión Técnica Nacional de Soja VII. Santa Fe, Argentina.

McDermontt JM, Brandele U, Dutly F, Haemmerli UA, Keller S, Muller KE, Wolfe MS. 1994. Genetic variation in powdery mildrew of barley: development of RAPD, SCAR and VNTR markers. Phytopathology 84:13161321.

McDonald BA. 1997. The population genetics of fungi: tools and techniques. Phytopathology 87:448-453.

Meng XQ, Soemaker RC, Yang XB. 1999. Analysis of pathogenicity and genetic variation among Phytophthora sojae isolates using RAPD. Mycol Res 103: 173-179.

Ne M. 1978. Estimation of average heterozigocity and genetic from a small numbers of individuals. Genetics 89:583-590.

Olah AF, Schmitthenner AF, Walker AK. 1985. Glyceollin accumulation in soybean lines tolerant to Phytophthora megasperma f. sp. glycinea. Phytopathology 75:542-546.

Peters RD, Clark RJ, Coffin AD, Sturz AV, Lambert DH, Miller JS. 2005. Limited genetic diversity in North American of Phytophthora erythroseptica pathogenic to potato based on RAPD analysis. Plant Dis 89:380-384.

Ploper LD. 2004. Economic importance of and control strategies for the major soybean diseases in Argentina. In: Proceedings of the World Soybean Research Conference VII, Foz de Iguazu, Brasil. p 606-614.

Prevost A, Wilkinson MJ. 1999. A new system of comparing PCR primers applied to ISSR fingerprinting of potato cultivars. Theo App Genet 98:107-112.

Rohlf JF. 1993. NTSYS-PC. Numerical taxonomy and multivariate analysis system. Versión 1.8. New York: Exeter Software Applied Biostatistics Inc.

Schmitthenner AF, Hobe M, Bhat RG. 1994. Phytophthora sojae races in Ohio over a 10-year interval. Plant Dis 78: 269-276.

Silva WPK, Karunanayake EN, Wijesundera RLC, Priyanka UMS. 2003. Genetic variation in Corynespora casiicola: a possible relationship between host origin and virulence. Mycol Res 107:567-571.

Sneath PH, Sokal RR. 1973. Numerical taxonomy: the principles and practice of numerical classification. San Francisco: W.H. Feeman \& Co.

Sokal RR, Rohlf JF. 1962. The comparison of dendrograma by objective methods. Taxon 11:33-40. 
Swofford DL, Selander RB. 1981. Biosys-1: a Fortran program for the comprehensive analysis of electrophoretic data in population genetics and systematics. J Heredity 72:281-283.

Tyler BM, Forster H, Coffey MD. 1995. Inheritance of avirulence factors and restriction fragment lengh polymorphism markers in outcrosses of the Oomycete Phytophthora sojae. Molec Plant-Microbe Interact 8: 515-523.

Vallone S, Botta G, Ploper D, Grijalba P, Gally M, Barreto D, Perez B. 1999. Incidencia de Phytophthora sojae en cultivos de soja en las regiones Pampeana Norte y Noroccidental de Argentina. In: Actas Mercosoja 99, Rosario, 21-25 Jun 1999. 1:21-23.
Wang HB, Wang XM, Zhu ZD. 2003. Analysis of genetic diversity of Phytophthora sojae isolates in China using RAPD. Mycosystema 22(2):219-227.

Whisson SC, Drenth A, MacLean DJ, Irwin JAG. 1994. Evidence for outcrossing in Phytophthora sojae and linkage of a DNA marker to two avirulent genes. Curr Genet 27:77-82.

Williams JGK, Kubelik AR, Rafalski JA, Tingey SV. 1990. DNA polymorphism amplified by arbitrary primers are useful as genetic markers. Nuc Acid Res 18:6531-6535.

Wrather JA, Anderson TR, Arsyad DM, Tan Y, Ploper LD, Porta-Puglia A, Ram HH, Yorinori JT. 2001. Soybean diseases loss estimates for the top ten soybean producing countries in 1998. Can J Plant Path 23:115-121. 